\title{
Role of vitamin $D$ receptor gene $C d x 2$ and Apa1 polymorphisms in prostate cancer susceptibility: a meta-analysis
}

\author{
Kewei Wang ${ }^{1}$, Guosheng $\mathrm{Wu}^{1}$, Jinping $\mathrm{Li}^{1}$ and Wentao Song ${ }^{2 *}$
}

\begin{abstract}
Background: Vitamin D receptor (VDR) gene polymorphisms affect the risk of prostate cancer. However, studies investigating the relationship between VDR gene polymorphisms ( $C d \times 2$ and $A p a l)$ and prostate cancer risk are equivocal. Therefore, we conducted a meta-analysis of all the studies to review the evidence available.

Methods: A comprehensive search of PubMed, EMBASE, and ISI Web of Science for studies published until September 2015 was conducted. Odds ratios (ORs) and $95 \%$ confidence intervals (Cls) were analyzed to determine the association between VDR Cdx2 and Apal polymorphisms, and prostate cancer risk.

Results: The meta-analysis included 10 studies involving 4979 cases and 4380 controls to analyze the VDR Cdx2 polymorphism. An additional 11 studies involving 2837 cases and 2884 controls were analyzed for the VDR Apal polymorphism. Evidence failed to support the role of VDR Cdx2 and Apal polymorphisms in prostate cancer. For C $d \times 2$, the pooled OR was 1.11 (95 \% Cl=0.93-1.33) for AA vs. GG genotypes, 0.97 ( $95 \% \mathrm{Cl}=0.88-1.06$ ) for GA vs. AA genotypes, 0.99 (95 \% Cl=0.91-1.08) for AA + GA vs. GG, and $1.12(95 \% \mathrm{Cl}=0.95-1.31)$ for AA vs. GA + GG. No significant relationship was observed in any subgroup analysis based on ethnicity, controls, and Hardy-Weinberg equilibrium (HWE). ORs for the Apal polymorphism were similar.
\end{abstract}

Conclusions: VDR Cdx2 and Apal polymorphisms are not associated with prostate cancer. Additional evidence is required to confirm this conclusion.

Abbreviations: VDR, Vitamin D receptor; HPC1, Hereditary prostate cancer gene 1; HWE, Hardy-Weinberg equilibrium; PCR-RFLP, Polymerase chain reaction - restriction fragment length polymorphism; SNP, Single nucleotide polymorphism; OR, Odds ratio; Cl, Confidence interval; HB, Hospital-based studies; PB, Population-based studies

\section{Background}

Prostate cancer ranks second among cancers diagnosed worldwide and sixth among cancer-related deaths in males. In 2012, more than 1.1 million cases were newly diagnosed worldwide. Prostate cancer accounts for $15 \%$ of all cancers in men, and nearly 759,000 are reported in developed countries. In 2012, prostate cancer ranked fifth among cancer-related deaths in men, accounting for nearly 307,000 deaths or $6.6 \%$ of all cancer-induced deaths in males [1]. Furthermore, the number of prostate cancers newly diagnosed annually is expected to climb

\footnotetext{
*Correspondence: songwentao99@126.com

${ }^{2}$ Nanchang Center for Disease Control and Prevention, 833 Lijing Road,

Nanchang, Jiangxi, People's Republic of China

Full list of author information is available at the end of the article
}

to $1,853,391$ worldwide by 2030 , resulting in almost 544,209 deaths [2]. Studies suggest that ethnicity, diet, aging, and genetic factors mediate the pathophysiology of prostate cancer [3-5]. Therefore, the prevalence of prostate cancer among African-Americans, Caucasians, and Asians varies [6].

The role of genetics in prostate cancer has been the focus of research attention in recent years. BRCA1 and $B R C A 2$ mutations increase the risk for ovarian and breast cancer as well as prostate cancer [7]. Hereditary prostate cancer gene 1 (HPC1), androgen and vitamin $\mathrm{D}$ receptors have been linked to prostate cancer [8]. Genome-wide association studies [9, 10] reported several SNPs substantially increasing the risk of prostate cancer. 
The role of testosterone and vitamin $\mathrm{D}$ in prostate cancer is mediated via vitamin $\mathrm{D}$ receptor (VDR). The hormonally active form of vitamin D1, 25dihydroxyvitamin D, inhibits cancer progression [11]. Vitamin D lowers the risk of several types of cancer, including prostate [12]. VDR is encoded by a large gene $(>100 \mathrm{~kb})$ mapped to chromosome 12q12-14. Its 14 exons spanning approximately $75 \mathrm{~kb}[13,14]$ exhibit a high degree of polymorphism, with at least 618 reported variants, most of which are either undetectable or occur at a low frequency in the general population. Among the known VDR polymorphisms, the most common SNPs, influencing the VDR expression in prostate cancer include FokI, BsmI, ApaI, $C d x 2$, and TaqI [15-18]. However, these associations between SNPs and prostate cancer are not proven. The role of BsmI, TaqI, and FokI polymorphisms in prostate cancer is not established [19, 20]. Similarly, ApaI and $C d x 2$ polymorphisms in prostate cancer risk are not validated $[15,16,21-28]$. For example, a case-controlled study showed a two-fold higher risk in Caucasian homozygous aa carriers for the variant ApaI compared with homozygous AA carriers [28]. Torkko reported that the $C d x 2$ polymorphism significantly increased the prostate cancer risk among Hispanic populations carrying the SRD5A2 V89L VV genotype [27]. However, a study conducted by Rowland found no relationship between prostate cancer and ApaI and $C d x 2$ SNPs [29].

The discrepancies may be attributed partly to statistical weakness, heterogeneity, population diversity, minimal effect of polymorphisms, and publication bias. We, therefore, investigated the role of VDR $C d x 2$ and ApaI polymorphisms in prostate cancer risk by conducting a meta-analysis of all the eligible case-controlled studies.

\section{Methods}

\section{Study selection}

We searched PubMed, EMBASE, and ISI Web of Science databases for genetic association studies involving VDR ApaI and $C d x 2$ polymorphisms and prostate cancer susceptibility, published through September 2015. We used combinations of the following keywords: 'prostate cancer', 'VDR' or 'vitamin D receptor', 'ApaI' or 'rs7975232', 'Cdx2' or 'rs11568820', and 'polymorphism', 'variant', or 'mutation'. Two independent investigators (Kewei Wang and Guosheng Wu) performed the search. Additional articles were retrieved via manual searches of reference lists in the studies identified initially. Our search was not restricted by publication date or language. Selected articles are listed in Table 1 with the following data: the first author, publication year, country, ethnicity, source of controls, number of cases and controls, polymorphisms, and Hardy-Weinberg equilibrium
(HWE) ( $P$ value). Other eligible studies were retrieved for additional review and data extraction. All the investigators were qualified and trained in literature search, statistical analysis, and evidence-based medicine.

\section{Inclusion and exclusion criteria}

The inclusion criteria were: (1) studies evaluating VDR $C d x 2$ and ApaI polymorphisms and prostate cancer risk; (2) clinical studies; (3) case-control studies; (4) studies investigating diseases confirmed histologically, pathologically and/or radiologically; (5) adequate genotype distributions to facilitate estimation of OR with $95 \% \mathrm{CI}$; and (6) most recent or complete studies. The exclusion criteria were:: (1) studies containing overlapping data; (2) missing genotype or allele frequencies; (3) absence of case controls; (4) studies not analyzing VDR $C d x 2$ and ApaI polymorphisms in prostate cancer susceptibility; (5) studies investigating progression, severity, phenotype modification, response to treatment, or survival; (6) inadequate data extraction; or (7) missing genotype frequencies.

\section{Meta-analysis}

ORs with $95 \%$ CIs were used to measure the relationship between VDR $C d x 2$ and ApaI polymorphisms, and prostate cancer risk. The $\mathrm{Z}$ test was used to evaluate the significance of pooled OR. $P$ value less than 0.05 was deemed significant. Homozygote, heterozygote, recessive and dominant models were used to determine the association of $C d x 2$ and ApaI polymorphisms with prostate cancer risk.

Statistical heterogeneity was evaluated using chi-squarebased Q-statistic [30] and $\mathrm{I}^{2}$ statistic [31]. $P<0.10$ or $\mathrm{I}^{2}>50 \%$ suggested statistically significant heterogeneity. A random effects model was used to calculate the pooled OR estimates. In other cases, a fixed effect model was used [32].

Sensitivity and subgroup analyses were used to explore the sources of heterogeneity among studies. Sequential exclusion of individual studies facilitated the evaluation of stability and sensitivity of the results. Subgroup analyses were based on ethnicity, controls and HWE.

Begg's funnel plots were used to determine publication bias in studies. Linear regression asymmetry was tested using the procedure described by Egger et al. [33]. An asymmetric plot suggested possible publication bias. $P$ value less than 0.05 in Egger's test indicated significant publication bias.

The statistical tests were conducted using STATA statistical software (version 12.0 STATA Corp., College Station, TX). All $P$ values were two-sided. The reliability and accuracy of the results were ensured by two authors independently evaluating the data with the same software. 
Table 1 Characteristics of eligible studies

\begin{tabular}{|c|c|c|c|c|c|c|c|c|c|}
\hline First author & Year & Country & Ethnicity & $\begin{array}{l}\text { Total sample size } \\
\text { (case/control) }\end{array}$ & $\begin{array}{l}\text { Genotyping } \\
\text { method }\end{array}$ & $\begin{array}{l}\text { Source of } \\
\text { control }\end{array}$ & Study & Polymorphisms & P for HWE \\
\hline \multirow[t]{2}{*}{ Gilbert [18] } & 2015 & UK & Caucasian & $951 / 898$ & Taqman & PB & NCC & $\mathrm{Cd} \times 2$ & 0.96 \\
\hline & & & & $950 / 890$ & Taqman & PB & NCC & Apal & 0.09 \\
\hline Jingwi [19] & 2015 & USA & African American & $446 / 379$ & TaqMan & PB & $\mathrm{CC}$ & Apa1 & 0.89 \\
\hline Yousaf [43] & 2014 & Pakistan & Asian & $47 / 134$ & PCR-RFLP & PB & $\mathrm{CC}$ & Apa1 & $<0.0001$ \\
\hline Jin Oh [41] & 2014 & Korean & Asian & $272 / 173$ & PCR-RFLP & $\mathrm{HB}$ & $\mathrm{CC}$ & $\mathrm{Cd} \times 2$ & - \\
\hline \multirow[t]{2}{*}{ Rowland (A) [56] } & 2012 & USA & African American & $414 / 223$ & TaqMan & PB & $\mathrm{CC}$ & $C d x-2$ & 0.07 \\
\hline & & & Caucasian & $1117 / 795$ & TaqMan & PB & $\mathrm{CC}$ & $C d x-2$ & 0.55 \\
\hline Bai [73] & 2009 & China & Asian & $122 / 130$ & PCR-RFLP & $\mathrm{HB}$ & $\mathrm{CC}$ & Apal & 0.21 \\
\hline Onen [28] & 2008 & Turkey & Caucasian & $133 / 157$ & PCR-RFLP & $\mathrm{HB}$ & CC & Apa1 & 0.41 \\
\hline \multirow[t]{2}{*}{ Torkko [27] } & 2008 & USA & Hispanic White & $141 / 273$ & TaqMan & PB & $\mathrm{CC}$ & $c d x-2$ & 0.05 \\
\hline & & & Caucasian & $444 / 488$ & TaqMan & PB & CC & $c d x-2$ & 0.99 \\
\hline Mikhak [26] & 2007 & USA & Caucasian & $688 / 689$ & TaqMan & PB & $\mathrm{CC}$ & $C d x-2$ & 0.15 \\
\hline Chaimuangraj [74] & 2006 & Thailand & Asian & $28 / 74$ & PCR-RFLP & $\mathrm{HB}$ & CC & Apa1 & 0.88 \\
\hline \multirow[t]{2}{*}{ Cicek [23] } & 2006 & USA & Caucasian & $439 / 479$ & TaqMan & PB & $C C$ & $\mathrm{Cd} \times 2$ & 0.26 \\
\hline & & & & $439 / 478$ & TaqMan & PB & $\mathrm{CC}$ & Apa1 & 0.25 \\
\hline John [24] & 2005 & USA & Caucasian & $417 / 435$ & TaqMan & PB & $\mathrm{CC}$ & $C d x-2$ & 0.75 \\
\hline Huang [15] & 2004 & Taiwan & Asian & $160 / 205$ & PCR-RFLP & $\mathrm{HB}$ & $\mathrm{CC}$ & Apa1 & 0.03 \\
\hline \multirow[t]{2}{*}{ Oakley-Girvan [25] } & 2004 & USA & African American & $113 / 121$ & PCR-RFLP & PB & $\mathrm{CC}$ & Apa1 & 0.16 \\
\hline & & & Caucasian & $232 / 171$ & PCR-RFLP & PB & $\mathrm{CC}$ & Apa1 & 0.19 \\
\hline Maistro [42] & 2004 & Brazil & mixed & $165 / 200$ & PCR-RFLP & PB & $\mathrm{CC}$ & Apa1 & - \\
\hline Bodiwala [22] & 2004 & UK & Caucasian & $368 / 243$ & PCR-RFLP & $\mathrm{HB}$ & $\mathrm{CC}$ & $c d x-2$ & 0.21 \\
\hline Suzuki [16] & 2003 & Japan & Asian & $81 / 105$ & PCR-RFLP & PB & CC & Apa1 & 0.007 \\
\hline Habuchi [21] & 2000 & Japan & Asian & $222 / 337$ & PCR-RFLP & $\mathrm{HB}$ & $\mathrm{CC}$ & Apa1 & 0.96 \\
\hline
\end{tabular}

\section{Results}

\section{Eligible studies}

The search terms returned 292 publications. We excluded 266 studies unrelated to Vitamin D receptor (VDR) gene polymorphism, three studies unrelated to prostate cancer [34-36], and three reviews [37-39]. The remaining 20 studies were included in the metaanalysis. We excluded two meta-analyses [20, 40], and two other studies [41, 42], which lacked genotype frequencies. No additional studies were retrieved following manual search of references in the published studies. Therefore, a total of 16 relevant studies were eligible for inclusion in the meta-analysis (Table 1). Three of the eligible studies reporting data involving two different ethnic groups were treated independently $[25,27]$. Therefore, the final meta-analysis included a total of 19 case-controlled studies as shown in Table 1. Seven studies involved 4979 cases and 4380 controls related to VDR $C d x 2$ polymorphism and prostate cancer risk, and 11 studies involved 2837 cases and 2884 controls related to VDR ApaI polymorphism.
The sample size ranged from 28 to 1117 individuals. Six of the eligible studies involved Caucasians and four were conducted in other ethnic groups to investigate VDR $C d x 2$ polymorphism. VDR ApaI polymorphisms were investigated in Caucasians in four studies. Six studies involved Asians, and two involved AfricanAmericans. Ten studies involved population samples, and six were hospital-based. PCR-RFLP and TaqMan assays were used to study the polymorphisms. The genotype distributions were not in HWE among the controls in two studies investigating VDR $C d x 2$ [27] and VDR ApaI $[15,16,43]$.

\section{Primary and subgroup analyses}

As shown in Table 2, VDR $C d x 2$ polymorphism was not significantly associated with prostate cancer risk in the pooled meta-analysis of all the eligible studies (homozygote model: $\mathrm{AA}$ vs. $\mathrm{GG}$ : $\mathrm{OR}=1.11,95 \% \mathrm{CI}=0.93-$ 1.33, $P=0.23$; heterozygote model: GA vs. AA: $\mathrm{OR}=$ 0.97, $95 \% \mathrm{CI}=0.88-1.06, P=0.53$; dominant model: $\mathrm{AA}+\mathrm{GA}$ vs. GG: $\mathrm{OR}=0.99,95 \% \mathrm{CI}=0.91-1.08, P=0.80$, Fig. 1; recessive model: AA vs. GA+ GG: $\mathrm{OR}=1.12$, 
Table 2 Meta-analysis of VDR Cdx2 polymorphism and prostate cancer risk

\begin{tabular}{|c|c|c|c|c|c|c|c|c|c|c|c|c|c|}
\hline \multirow[b]{2}{*}{ Analysis } & \multirow{2}{*}{ N } & \multicolumn{3}{|c|}{ Homozygote (AA vs. GG) } & \multicolumn{3}{|c|}{ Heterozygote (GA vs. GG) } & \multicolumn{3}{|c|}{ Dominant model (AA + GA vs. GG) } & \multicolumn{3}{|c|}{ Recessive model (AA vs. GA + GG) } \\
\hline & & OR $(95 \% \mathrm{Cl})$ & $P$ & $1^{2}(\%)$ & $\mathrm{OR}(95 \% \mathrm{Cl})$ & $P$ & $1^{2}(\%)$ & OR $(95 \% \mathrm{Cl})$ & $\mathrm{P}$ & $1^{2}(\%)$ & $\mathrm{OR}(95 \% \mathrm{Cl})$ & $\mathrm{P}$ & $I^{2}(\%)$ \\
\hline Overall & 9 & $1.11(0.93-1.33)$ & 0.23 & 32.3 & $0.97(0.88-1.06)$ & 0.53 & 12.9 & $0.99(0.91-1.08)$ & 0.80 & 28.4 & $1.12(0.95-1.31)$ & 0.16 & 17.6 \\
\hline \multicolumn{14}{|l|}{ Ethnicity } \\
\hline Caucasian & 6 & $1.13(0.92-1.39)$ & 0.23 & 23.0 & $0.93(0.84-1.03)$ & 0.201 & 0 & $0.96(0.88-1.06)$ & 0.45 & 4.4 & $1.15(0.94-1.41)$ & 0.15 & 16.7 \\
\hline African American & 1 & $1.80(0.97-3.32)$ & 0.06 & - & $1.54(0.81-2.92)$ & 0.18 & - & $1.70(0.94-3.10)$ & 0.08 & - & $1.26(0.91-1.75)$ & 0.16 & - \\
\hline Hispanic White & 1 & $0.49(0.17-1.36)$ & 0.17 & - & $0.83(0.52-1.31)$ & 0.43 & - & $0.77(0.50-1.19)$ & 0.24 & - & $0.52(0.18-1.43)$ & 0.20 & - \\
\hline Mixed & 1 & $0.94(0.58-1.50)$ & 0.80 & - & $1.15(0.91-1.44)$ & 0.22 & - & $1.12(0.90-1.39)$ & 0.31 & - & $0.89(0.56-1.42)$ & 0.64 & - \\
\hline \multicolumn{14}{|l|}{ Source of control } \\
\hline$P B$ & 8 & $1.11(0.92-1.33)$ & 0.259 & 40.7 & $0.95(0.86-1.04)$ & 0.32 & 0 & $0.97(0.89-1.06)$ & 0.54 & 23.8 & $1.12(0.95-1.32)$ & 0.16 & 27.7 \\
\hline$H B$ & 1 & $1.11(0.93-1.32)$ & 0.686 & - & $1.26(0.88-1.80)$ & 0.19 & - & $1.25(0.89-1.75)$ & 0.19 & - & $1.07(0.52-2.18)$ & 0.85 & - \\
\hline \multicolumn{14}{|l|}{ HWE in controls } \\
\hline Yes & 8 & $1.15(0.95-1.40)$ & 0.133 & $34.3 \%$ & $0.97(0.89-1.07)$ & 0.65 & 22.1 & $0.99(0.91-1.09)$ & 0.99 & 34.6 & $1.15(0.97-1.36)$ & 0.09 & 20.2 \\
\hline No & 1 & $0.87(0.54-1.40)$ & 0.58 & - & $0.91(0.69-1.21)$ & 0.53 & - & $0.90(0.69-1.17)$ & 0.46 & - & $0.90(0.57-1.43)$ & 0.67 & - \\
\hline
\end{tabular}

$P P$ values for $Z$ test, $O R$ odds ratio, $C l$ confidence intervals, $H B$ hospital-based studies, $P B$ population-based studies, $H W E$ Hardy-Weinberg equilibrium

$95 \% \mathrm{CI}=0.95-1.31, P=0.16)$. Subgroup analyses based on ethnicity, source of control, and HWE in controls, revealed no significant association.

As shown in Table 3, VDR ApaI polymorphism was not significantly correlated with prostate cancer risk in pooled analysis of eligible studies (homozygote model: AA vs. aa, $\mathrm{OR}=0.97,95 \% \mathrm{CI}: 0.76-1.25, P=0.85$; heterozygote model: $A a$ vs. aa: $\mathrm{OR}=1.00,95 \% \mathrm{CI}$ : $0.88-1.13, P=0.99$; dominant model: $\mathrm{AA}+\mathrm{Aa}$ vs. aa: $\mathrm{OR}=0.98,95 \%$ CI: 0.87-1.10, $P=0.79$, Fig. 2; recessive model: $\mathrm{AA}$ vs. $\mathrm{Aa}+\mathrm{aa}: \mathrm{OR}=0.97,95 \%$ CI: $0.85-1.01$,
$P=0.64$ ). Subgroup analyses based on ethnicity, source of controls, and HWE in controls, revealed the absence of prostate cancer risk with VDR ApaI polymorphism.

\section{Heterogeneity analysis and sensitivity analysis}

Significant heterogeneity was found in AA vs. Aa genetic model of VDR ApaI polymorphism ( $\left.P=0.021, \mathrm{I}^{2}=51.1 \%\right)$. Sensitivity analysis was conducted by excluding individual studies to determine heterogeneity. Sequential exclusion of individual case-controlled study revealed similar results

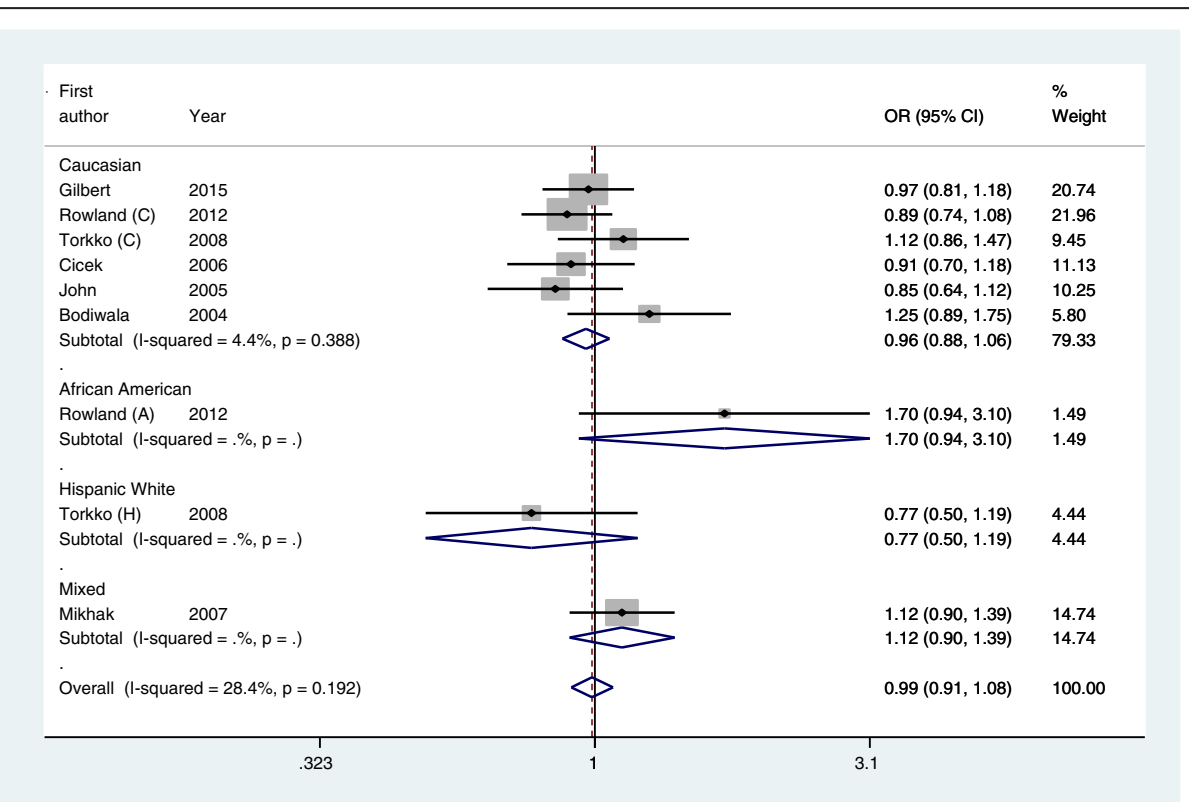

Fig. 1 Forest plot of VDR Cdx2 polymorphism and prostate cancer risk using a fixed-effect model (dominant model $A A+G A$ vs. GG) 
Table 3 Meta-analysis of VDR Apal polymorphism and prostate cancer risk

\begin{tabular}{|c|c|c|c|c|c|c|c|c|c|c|c|c|c|}
\hline \multirow[b]{2}{*}{ Analysis } & \multirow[b]{2}{*}{$\mathrm{N}$} & \multicolumn{3}{|c|}{ Homozygote (AA vs. aa) } & \multicolumn{3}{|c|}{ Heterozygote (Aa vs. aa) } & \multicolumn{3}{|c|}{ Dominant model (AA + Aa vs. aa) } & \multicolumn{3}{|c|}{ Recessive model (AA vs. $\mathrm{Aa}+\mathrm{aa}$ ) } \\
\hline & & OR $(95 \% \mathrm{Cl})$ & $P$ & $1^{2}(\%)$ & OR $(95 \% \mathrm{Cl})$ & $P$ & $I^{2}(\%)$ & OR $(95 \% \mathrm{Cl})$ & $P$ & $1^{2}(\%)$ & OR $(95 \%$ Cl) & $P$ & $1^{2}(\%)$ \\
\hline Overall & 9 & $0.97(0.76-1.25)$ & 0.85 & 51.1 & $1.00(0.88-1.13)$ & 0.99 & 28.8 & $0.98(0.87-1.10)$ & 0.79 & 0 & $0.97(0.85-1.01)$ & 0.64 & 0 \\
\hline \multicolumn{14}{|l|}{ Ethnicity } \\
\hline Caucasian & 4 & $0.81(0.66-1.01)$ & 0.06 & 11.0 & $1.01(0.85-1.19)$ & 0.91 & 20.8 & $0.94(0.81-1.10)$ & 0.46 & 20.8 & $0.92(0.78-1.06)$ & 0.25 & 0 \\
\hline African American & 2 & $1.54(0.74-3.19)$ & 0.24 & 57.9 & $1.16(0.84-1.60)$ & 0.35 & 0 & $1.27(0.94-1.72)$ & 0.12 & 0 & $0.92(0.65-1.29)$ & 0.63 & 0 \\
\hline Asian & 6 & $1.05(0.69-1.58)$ & 0.82 & 36.2 & $0.90(0.71-1.14)$ & 0.40 & 49.0 & $0.93(0.76-1.16)$ & 0.56 & 0 & $1.24(0.92-1.66)$ & 0.14 & 0 \\
\hline \multicolumn{14}{|l|}{ Source of control } \\
\hline$P B$ & 8 & $1.03(0.77-1.38)$ & 0.82 & 60.1 & $1.05(0.91-1.20)$ & 0.52 & 42.9 & $1.02(0.90-1.16)$ & 0.72 & 0 & $0.97(0.85-1.11)$ & 0.64 & 17.8 \\
\hline$H B$ & 4 & $0.82(0.50-1.34)$ & 0.43 & 29.3 & $0.83(0.63-1.10)$ & 0.20 & 0 & $0.84(0.65-1.09)$ & 0.18 & 0 & $0.98(0.69-1.38)$ & 0.92 & 0 \\
\hline \multicolumn{14}{|l|}{ HWE in controls } \\
\hline Yes & 10 & $0.96(0.76-1.21)$ & 0.733 & 36.6 & $1.01(0.89-1.15)$ & 0.90 & 0 & $0.99(0.87-1.12)$ & 0.86 & 0 & $0.93(0.82-1.06)$ & 0.29 & 0 \\
\hline No & 2 & $0.86(0.19-3.86)$ & 0.84 & 86.7 & $0.91(0.59-1.40)$ & 0.66 & 85.6 & $0.98(0.88-1.10)$ & 0.74 & 0 & $1.56(0.99-2.46)$ & 0.05 & 0 \\
\hline
\end{tabular}

$P P$ values for $Z$ test, $O R$ odds ratio, $C l$ confidence intervals, $H B$ hospital-based studies, $P B$ population-based studies, $H W E$ Hardy-Weinberg equilibrium, $N R$ not reported

statistically, indicating the stability and sensitivity of the meta-analysis (data not shown).

Population and subgroup analysis revealed no significant heterogeneity in terms of VDR $C d x 2$ polymorphism.

\section{Publication bias}

Symmetrical Begg's funnel plots indicated the absence of publication bias in the overall meta-analysis (Fig. 3). Egger's test results revealed no publication bias in studies investigatingVDR $C d x 2$ polymorphism $(P=0.67$ for AA vs. GG; $P=0.24$ for GA vs. GG; $P=0.34$ for dominant model AA + GA vs. GG; and $P=0.248$ for recessive model AA vs. GA + GG) and VDR ApaI ( $P=0.80$ for AA vs. aa; $P=0.78$ for Aa vs. aa; $P=0.48$ for dominant model AA + Aa vs. aa; and $P=0.14$ for recessive model AA vs. $\mathrm{Aa}+\mathrm{aa})$.

\section{Discussion}

Genetic polymorphisms play a key role in the pathophysiology of disease. Genome-wide association studies (GWAS) reported more than 90 common SNPs (minor allele frequency [MAF], $5 \%$ or greater) with established relationship involving insignificant alterations (average per allele odds ratios [ORs]:1.1-1.3) in prostate cancer susceptibility [44-47]. Overall, the SNPs account for a third of the total inherited risk of prostate cancer [44, 45].

VDR is a nuclear receptor regulating bone mineral homeostasis, mammalian hair cycle, and compound

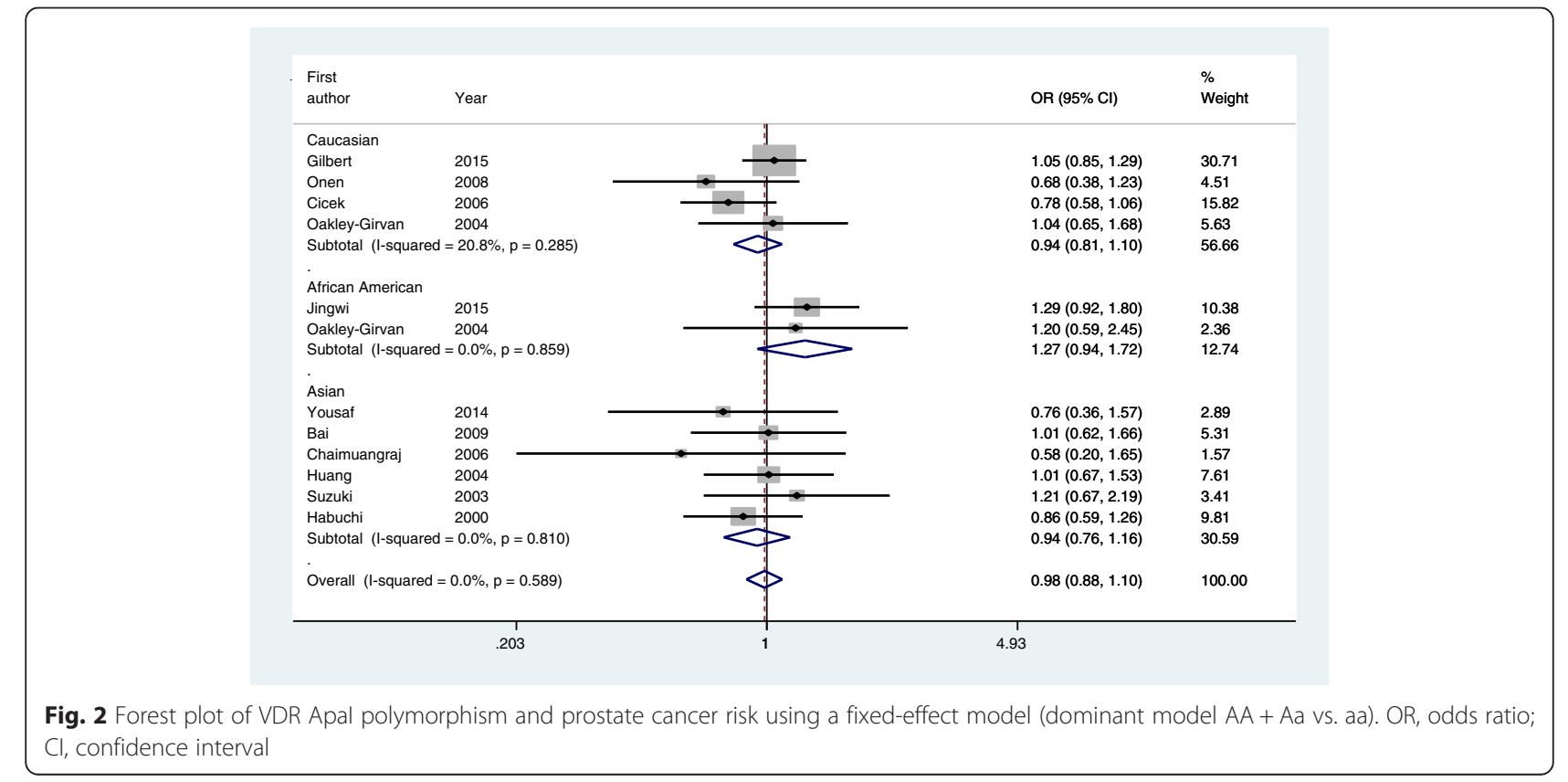




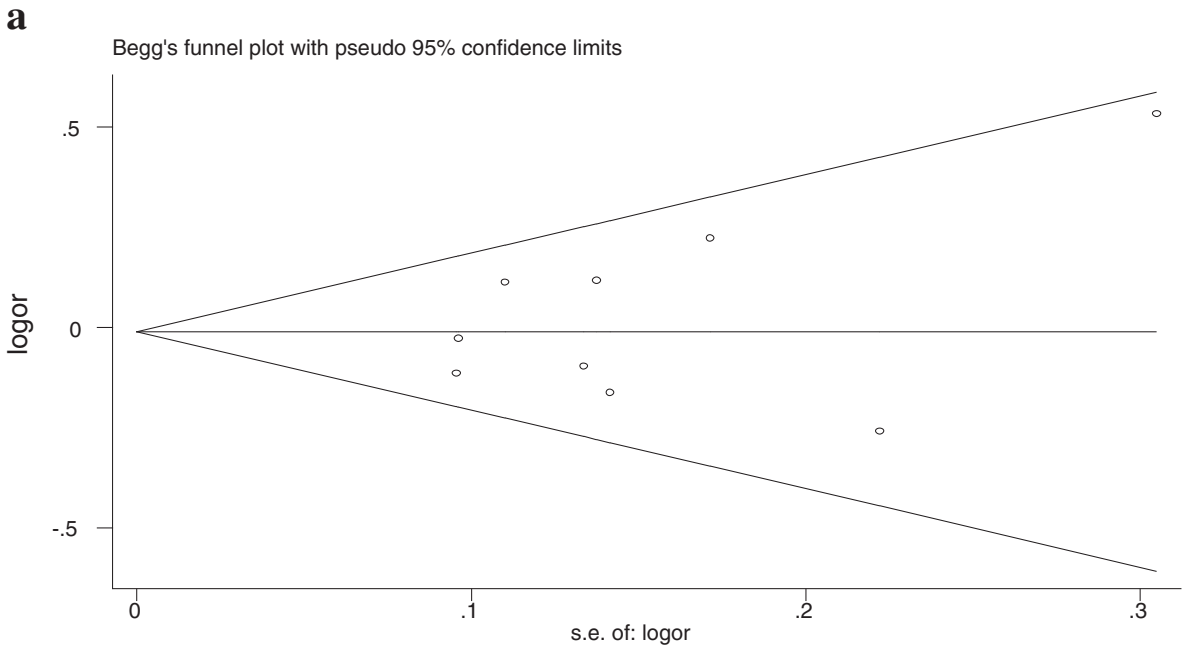

b

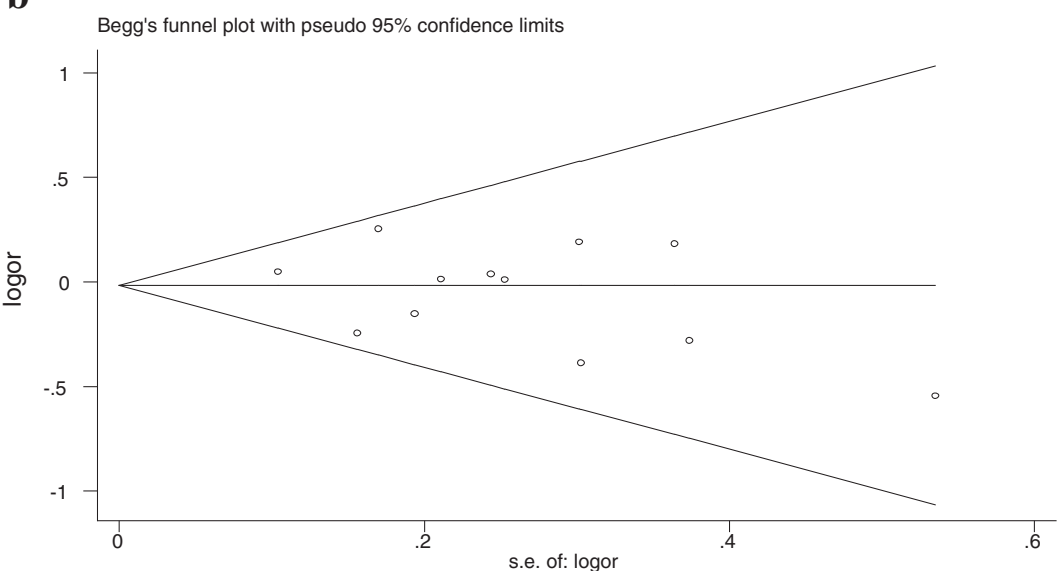

Fig. 3 Funnel plot analysis for detection of publication bias. Each point represents a separate study for the indicated association. a Funnel plot: dominant model $A A+G A$ vs. GG of VDR Cdx2 polymorphism in overall analysis ( $P=0.67)$ and (b) Funnel plot: dominant model $A A+A a$ vs. aa of VDR Apal polymorphism in overall analysis $(P=0.48)$

detoxification. It has recently been found to prevent tumorigenesis by inhibiting cell proliferation and differentiation, and inducing apoptosis. Previous studies demonstrated that VDR gene polymorphisms, which include FokI, BsmI, ApaI, TaqI, and Cdx2, are associated with ovarian [48], skin [49], breast [50], and colorectal cancers [51].

The G-to-A polymorphism involving a Cdx2-binding site in the 1e promoter region, mediates VDR transcription in intestine [52]. The strong binding of A allele with the $\mathrm{Cdx} 2$ transcription factor enhances transcriptional activity [53]. Thus, Cdx2 regulates cellular proliferation and differentiation. The $\mathrm{A}$ allele frequencies varied in different ethnic groups: $74 \%$ in Africans, $43 \%$ in Asians, and $19 \%$ in Caucasians [54].

$C d x 2$ polymorphism prevents osteoporosis [53]. The ApaI polymorphisms (in intron 8) at the $3^{\prime}$ untranslated region (UTR) are in strong linkage disequilibrium (LD)
[54]. Nonetheless, the polymorphism does not alter the predicted amino acid sequence of the VDR, and often affects mRNA stability and the efficiency of protein translation [55]. Several studies investigated the role of VDR $C d x 2$ and ApaI polymorphisms in prostate cancer risk, with inconclusive results. Therefore, we conducted a meta-analysis to establish the association between VDR $C d x 2$ and ApaI polymorphisms, and prostate cancer risk.

Our meta-analysis, including 6427 cases and 6039 controls from 16 case-controlled studies, evaluated the association between $C d x 2$ and ApaI polymorphisms, and prostate cancer risk. Our results suggest that these polymorphisms do not increase the risk of prostate risk in genetic models, which was consistent with a previous meta-analysis [20]. However, our current meta-analysis included 6427 cases and 6039 controls from 16 casecontrolled studies to obtain comprehensive results. 
Subgroup analysis based on ethnicity, source of control, and HWE in controls, showed no significant relationship between $C d x 2$ and ApaI polymorphisms, and prostate cancer risk in any comparative studies.

The role of VDR $C d x 2$ and ApaI polymorphisms in prostate cancer was unclear due to ethnic variation in genotypes, controls and subjects, and genotyping techniques [16]. The VDR $C d x 2$ AA genotype is most frequently found in African-Americans (58.9 \%) [56], while the GG genotype occurs most frequently in Hispanic Whites $(65.7 \%)$ [27].

The VDR ApaI genotype AA is the most prevalent in African-Americans (40.2\%) [25], while the aa genotype is most frequently found in Asians (67.9 \%) [43]. However, the African study sample included three studies involving African-Americans, preventing statistical interpretation with confidence. A larger sample size is needed for subgroup analysis of various ethnic populations.

Furthermore, a few hospital-based studies did not support the association of increased risk with VDR polymorphisms compared with normal controls [57, 58], in contrast to other investigations [21, 59]. In subgroup analyses by source of control, we selected 16 studies (eight studies related to VDR $C d x 2$ polymorphism and eight involving VDR ApaI polymorphism) which included subjects from more representative populations to determine potential gene association in tumorigenesis.

The relationship between VDR $C d x 2$ and ApaI polymorphisms, and prostate cancer risk in previous studies is attributed to differences in lifestyle and disease prevalence as well as limited sample size [60-62]. Further, prostate size, cancer stage, and depth of invasion were not considered, in determining the genotypic distribution. Prostate cancer is a complex and multifactorial disease mediated by genetic and environmental factors in different populations [60].

However, the risk factors underlying prostate cancer are related to each other. Similar gene polymorphisms may still result in different phenotypes, because the penetrance of the mutation depends on the interaction with other polymorphisms and exposure to specific environment.

Genetic heterogeneity in meta-analysis of studies investigating genetic polymorphisms and various diseases is not surprising. However, no heterogeneity was observed among studies investigating the VDR $C d x 2$ polymorphism in our meta-analysis. Different genotype distributions and population stratification may also alter genotype-phenotype associations.

Furthermore, a number of factors affect heterogeneity. Different studies select subjects for control groups based on different definitions, resulting in heterogeneity observed in our meta-analysis. We investigated whether the heterogeneity might be explained by potential confounding factors such as age, smoking, drinking, androgen levels, and other clinical characteristics. However, no reliable results were available due to lack of access to individual data involving these variables. Similar heterogeneity was observed with the VDR ApaI polymorphism.

Cancer is a complex disease, and is triggered by genetic factors as well as environmental impact (UV exposure), gene interactions, and lifestyle (e.g., smoking, drinking alcohol, and diet) [63-71]. Interaction between environmental factors and VDR gene is also a possibility [70, 72]. Further large studies investigating the different types of VDR $C d x 2$ and ApaI polymorphisms are needed to facilitate subgroup analyses. Environmental interaction with VDR $C d x 2$ and ApaI polymorphisms and its role in prostate cancer risk needs to be validated.

The study limitations of our meta-analysis are as follows. First, in subgroup analyses based on ethnicity, the population sample size was comparatively small, which may affect the statistical power in determining the significance of the relationship. Second, our results were not adjusted for variables such as age, smoking, drinking, obesity, gene-gene interactions, and environmental factors, due to lack of access to the original study data. Finally, most studies investigating the VDR $C d x 2$ polymorphism in prostate cancer risk involved Caucasian population. Therefore, evidence based on large controlled studies involving a wide range of ethnic and population groups is needed to re-evaluate the association between specific SNPs and prostate cancer risk.

\section{Conclusions}

Our findings suggest that VDR $C d x 2$ and ApaI polymorphisms are not linked to prostate cancer susceptibility in the overall population. Epidemiological studies with large sample sizes including a wide range of ethnic populations and functional parameters are needed to reinforce our findings.

\section{Acknowledgments}

We thank Zihui Tan from the Department of Bioinformatics of Tongji University, and Jie Hu from the Department of Biology, Fudan University, for their assistance with literature search.

\section{Funding}

This study was supported by the young teachers' startup fund for scientific research at Jiangnan University (JUSRP11569), the plan of public health research center of Jiangnan University (JUPH201508) and the project of Wuxi science and technology supporting plan (WX0302-B010507-150016-PB).

\section{Availability of data and materials Not applicable.}

\section{Authors' contributions}

KWW and WTS conceived and designed the study, KWW, GSW, JPL and WTS participated in study selection, data extraction and statistical analysis. KWW and WTS were involved in manuscript drafting and revision. All authors approved the final manuscript for submission and publication. 


\section{Authors' information}

Not applicable.

\section{Competing interests}

The authors declare that they have no competing interests.

\section{Consent for publication}

Not applicable.

\section{Ethics approval and consent to participate}

Not applicable.

\section{Author details}

${ }^{1}$ Wuxi Medical School, Jiangnan University, Wuxi, Jiangsu 214122, People's Republic of China. ${ }^{2}$ Nanchang Center for Disease Control and Prevention, 833 Lijing Road, Nanchang, Jiangxi, People's Republic of China.

\section{Received: 23 September 2015 Accepted: 14 August 2016} Published online: 23 August 2016

\section{References}

1. Ferlay J, Soerjomataram I, Dikshit R, Eser S, Mathers C, Rebelo M, et al. Cancer incidence and mortality worldwide: sources, methods and major patterns in GLOBOCAN 2012. Int J Cancer. 2015;136(5):E359-86.

2. World Health Organization, International Agency for Research on Cancer. GLOBOCAN 2012: estimated Cancer incidence and mortality worldwide in 2012- ONLINE ANALYSIS > PREDICTION. Available at: http://globocan.iarc.fr/ Pages/burden_sel.aspx.

3. Cussenot $\mathrm{O}$, Valeri $\mathrm{A}$. Heterogeneity in genetic susceptibility to prostate cancer. Eur J Intern Med. 2001;12:11-6.

4. Carter BS, Bova GS, Beaty TH, Steinberg GD, Childs B, Isaacs WB, et al. Hereditary prostate cancer: epidemiologic and clinical features. J Urol. 1993;150:797-802

5. Xia SJ, Cui D, Jiang Q. An overview of prostate diseases and their characteristics specific to Asian men. Asian J Androl. 2012;14:458-64.

6. Hoffman RM, Gilliland FD, Eley JW, Harlan LC, Stephenson RA, Stanford JL, et al. Racial and ethnic differences in advanced-stage prostate cancer: the Prostate Cancer Outcomes Study. J Natl Cancer Inst. 2001:93:388-95.

7. Struewing JP, Hartge P, Wacholder S, Baker SM, Berlin M, McAdams M, et al. The risk of cancer associated with specific mutations of BRCA1 and BRCA2 among Ashkenazi Jews. N Engl J Med. 1997:336:1401-8.

8. Gallagher RP, Fleshner N. Prostate cancer: 3. Individual risk factors. CMAJ 1998:159:807-13

9. Eeles RA, Kote-Jarai Z, Giles GG, Olama AA, Guy M, Jugurnauth SK, et al. Multiple newly identified loci associated with prostate cancer susceptibility. Nat Genet. 2008;40:316-21.

10. Thomas G, Jacobs KB, Yeager M, Kraft P, Wacholder S, Orr N, et al. Multiple loci identified in a genome-wide association study of prostate cancer. Nat Genet. 2008:40:310-5.

11. Feldman D. Androgen and vitamin D receptor gene polymorphisms: the long and short of prostate cancer risk. J Natl Cancer Inst. 1997:89:109-11.

12. Hendrickson WK, Flavin R, Kasperzyk JL, Fiorentino M, Fang F, Lis R, et al. Vitamin $D$ receptor protein expression in tumor tissue and prostate cancer progression. J Clin Oncol. 2011;29:2378-85.

13. Labuda M, Fujiwara TM, Ross MV, Morgan K, Garcia-Heras J, Ledbetter DH, et al. Two hereditary defects related to vitamin D metabolism map to the same region of human chromosome 12q13-14. J Bone Miner Res. 1992; 7:1447-53.

14. Crofts LA, Hancock MS, Morrison NA, Eisman JA. Multiple promoters direct the tissue-specific expression of novel N-terminal variant human vitamin D receptor gene transcripts. Proc Natl Acad Sci U S A. 1998;95:10529-34.

15. Huang SP, Chou YH, Wayne CW, Wu MT, Chen YY, Yu CC, et al. Association between vitamin $\mathrm{D}$ receptor polymorphisms and prostate cancer risk in a Taiwanese population. Cancer Lett. 2004;207:69-77.

16. Suzuki K, Matsui $H$, Ohtake N, Nakata S, Takei T, Koike $H$, et al. Vitamin D receptor gene polymorphism in familial prostate cancer in a Japanese population. Int J Urol. 2003:10:261-6.

17. Gilbert R, Metcalfe C, Fraser WD, Lewis S, Donovan J, Hamdy F, et al. Associations of circulating 25-hydroxyvitamin D, 1,25-dihydroxyvitamin D, and vitamin $D$ pathway genes with prostate-specific antigen progression in men with localized prostate cancer undergoing active monitoring. Eur J Cancer Prev. 2013:22:121-5.

18. Gilbert R, Bonilla C, Metcalfe C, Lewis S, Evans DM, Fraser WD, et al. Associations of vitamin D pathway genes with circulating 25hydroxyvitamin-D, 1,25-dihydroxyvitamin-D, and prostate cancer: a nested case-control study. Cancer Causes Control. 2015:26:205-18.

19. Jingwi EY, Abbas M, Ricks-Santi L, Winchester D, Beyene D, Day A, et al. Vitamin D receptor genetic polymorphisms are associated with PSA level, Gleason score and prostate cancer risk in African-American men. Anticancer Res. 2015;35:1549-58.

20. Yin $M$, Wei $S$, Wei Q. Vitamin D receptor genetic polymorphisms and prostate cancer risk: a meta-analysis of 36 published studies. Int J Clin Exp Med. 2009:2:159-75.

21. Habuchi T, Suzuki T, Sasaki R, Wang L, Sato K, Satoh S, et al. Association of vitamin $D$ receptor gene polymorphism with prostate cancer and benign prostatic hyperplasia in a Japanese population. Cancer Res. 2000;60:305-8.

22. Bodiwala D, Luscombe CJ, French ME, Liu S, Saxby MF, Jones PW, et al. Polymorphisms in the vitamin D receptor gene, ultraviolet radiation, and susceptibility to prostate cancer. Environ Mol Mutagen. 2004;43:121-7.

23. Cicek MS, Liu X, Schumacher FR, Casey G, Witte JS. Vitamin D receptor genotypes/haplotypes and prostate cancer risk. Cancer Epidemiol Biomarkers Prev. 2006;15:2549-52.

24. John EM, Schwartz GG, Koo J, Van Den Berg D, Ingles SA. Sun exposure, vitamin $\mathrm{D}$ receptor gene polymorphisms, and risk of advanced prostate cancer. Cancer Res. 2005:65:5470-9.

25. Oakley-Girvan I, Feldman D, Eccleshall TR, Gallagher RP, Wu AH, Kolonel LN, et al. Risk of early-onset prostate cancer in relation to germ line polymorphisms of the vitamin D receptor. Cancer Epidemiol Biomarkers Prev. 2004;13:1325-30.

26. Mikhak B, Hunter DJ, Spiegelman D, Platz EA, Hollis BW, Giovannucci E. Vitamin D receptor (VDR) gene polymorphisms and haplotypes, interactions with plasma 25-hydroxyvitamin D and 1,25-dihydroxyvitamin D, and prostate cancer risk. Prostate. 2007:67:911-23.

27. Torkko KC, van Bokhoven A, Mai P, Beuten J, Balic I, Byers TE, et al. VDR and SRD5A2 polymorphisms combine to increase risk for prostate cancer in both non-Hispanic White and Hispanic White men. Clin Cancer Res. 2008;14:3223-9.

28. Onen IH, Ekmekci A, Eroglu M, Konac E, Yesil S, Biri H. Association of genetic polymorphisms in vitamin D receptor gene and susceptibility to sporadic prostate cancer. Exp Biol Med (Maywood). 2008;233:1608-14.

29. Rowland GW, Schwartz GG, John EM, Ingles SA. Calcium intake and prostate cancer among African Americans: effect modification by vitamin $D$ receptor calcium absorption genotype. J Bone Miner Res. 2012;27:187-94.

30. Lau J, loannidis JP, Schmid CH. Quantitative synthesis in systematic reviews. Ann Intern Med. 1997:127:820-6.

31. Higgins JP, Thompson SG, Deeks JJ, Altman DG. Measuring inconsistency in meta-analyses. BMJ. 2003:327:557-60.

32. Midgette AS, Wong JB, Beshansky JR, Porath A, Fleming C, Pauker SG. Costeffectiveness of streptokinase for acute myocardial infarction: a combined meta-analysis and decision analysis of the effects of infarct location and of likelihood of infarction. Med Decis Making. 1994;14:108-17.

33. Egger M, Davey SG, Schneider M, Minder C. Bias in meta-analysis detected by a simple, graphical test. BMJ. 1997;315:629-34.

34. Huang QQ, Liao YY, Ye XH, Fu JJ, Chen SD. Association between VDR polymorphisms and breast cancer: an updated and comparative metaanalysis of crude and adjusted odd ratios. Asian Pac J Cancer Prev. 2014;15:847-53.

35. Zhou ZC, Wang J, Cai ZH, Zhang QH, Cai ZX, Wu JH. Association between vitamin $D$ receptor gene $C d \times 2$ polymorphism and breast cancer susceptibility. Tumour Biol. 2013;34:3437-41.

36. Aydingoz IE, Bingul I, Dogru-Abbasoglu S, Vural P, Uysal M. Analysis of vitamin $D$ receptor gene polymorphisms in vitiligo. Dermatology. 2012;224:361-8

37. Gandini S, Gnagnarella P, Serrano D, Pasquali E, Raimondi S. Vitamin D receptor polymorphisms and cancer. Adv Exp Med Biol. 2014;810:69-105.

38. Kostner K, Denzer N, Muller CS, Klein R, Tilgen W, Reichrath J. The relevance of vitamin D receptor (VDR) gene polymorphisms for cancer: a review of the literature. Anticancer Res. 2009:29:3511-36.

39. Chen L, Davey SG, Evans DM, Cox A, Lawlor DA, Donovan J, et al. Genetic variants in the vitamin d receptor are associated with advanced prostate cancer at diagnosis: findings from the prostate testing for cancer and treatment study and a systematic review. Cancer Epidemiol Biomarkers Prev. 2009;18:2874-81. 
40. Huang J, Huang J, Ma Y, Wang H, Yang J, Xiong T, et al. The Cdx-2 polymorphism in the VDR gene is associated with increased risk of cancer: a meta-analysis. Mol Biol Rep. 2013;40:4219-25.

41. Oh JJ, Byun SS, Lee SE, Hong SK, Jeong CW, Kim D, et al. Genetic variations in VDR associated with prostate cancer risk and progression in a Korean population. Gene. 2014:533:86-93.

42. Maistro S, Snitcovsky I, Sarkis AS, Da SI, Brentani MM. Vitamin D receptor polymorphisms and prostate cancer risk in Brazilian men. Int J Biol Markers. 2004;19:245-9.

43. Yousaf N, Afzal S, Hayat T, Shah J, Ahmad N, Abbasi R, et al. Association of vitamin $\mathrm{D}$ receptor gene polymorphisms with prostate cancer risk in the Pakistani population. Asian Pac J Cancer Prev. 2014;15:10009-13.

44. Eeles RA, Olama AA, Benlloch S, Saunders EJ, Leongamornlert DA, Tymrakiewicz $M$, et al. Identification of 23 new prostate cancer susceptibility loci using the iCOGS custom genotyping array. Nat Genet. 2013; 45:385-91, 391e.

45. Olumi AF. Commentary on "identification of 23 new prostate cancer susceptibility loci using the iCOGS custom genotyping array." Eeles RA, Olama AA, Benlloch S, Saunders EJ, Leongamornlert DA, Tymrakiewicz M, Ghoussaini M, Luccarini C, Dennis J, Jugurnauth-Little S, Dadaev T, Neal DE, Hamdy FC, Donovan JL, Muir K, Giles GG, Severi G, Wiklund F, Gronberg H, Haiman CA, Schumacher F, Henderson BE, Le Marchand L, Lindstrom S, Kraft P, Hunter DJ, Gapstur S, Chanock SJ, Berndt SI, Albanes D, Andriole G, Schleutker J, Weischer M, Canzian F, Riboli E, Key TJ, Travis RC, Campa D, Ingles SA, John EM, Hayes RB, Pharoah PD, Pashayan N, Khaw KT, Stanford JL, Ostrander EA, Signorello LB, Thibodeau SN, Schaid D, Maier C, Vogel W, Kibel AS, Cybulski C, Lubinski J, Cannon-Albright L, Brenner H, Park JY, Kaneva R, Batra J, Spurdle AB, Clements JA, Teixeira MR, Dicks E, Lee A, Dunning AM, Baynes C, Conroy D, Maranian MJ, Ahmed S, Govindasami K, Guy M, Wilkinson RA, Sawyer EJ, Morgan A, Dearnaley DP, Horwich A, Huddart RA, Khoo VS, Parker CC, Van As NJ, Woodhouse CJ, Thompson A, Dudderidge T, Ogden C, Cooper CS, Lophatananon A, Cox A, Southey MC, Hopper JL, English DR, Aly M, Adolfsson J, Xu J, Zheng SL, Yeager M, Kaaks R, Diver WR, Gaudet MM, Stern MC, Corral R, Joshi AD, Shahabi A, Wahlfors T, Tammela TL, Auvinen A, Virtamo J, Klarskov P, Nordestgaard BG, Roder MA, Nielsen SF, Bojesen SE, Siddiq A, Fitzgerald LM, Kolb S, Kwon EM, Karyadi DM, Blot WJ, Zheng W, Cai Q, McDonnell SK, Rinckleb AE, Drake B, Colditz G, Wokolorczyk D, Stephenson RA, Teerlink C, Muller H, Rothenbacher D, Sellers TA, Lin HY, Slavov C, Mitev V, Lose F, Srinivasan S, Maia S, Paulo P, Lange E, Cooney KA, Antoniou AC, Vincent D, Bacot F, Tessier DC; COGSCancer Research UK GWAS-ELLIPSE (part of GAME-ON) Initiative; Australian Prostate Cancer Bioresource; UK Genetic Prostate Cancer Study Collaborators/ British Association of Urological Surgeons' Section of Oncology; UK ProtecT (Prostate testing for cancer and Treatment) Study. Urol Oncol. 2014;32:211.

46. Goh CL, Schumacher FR, Easton D, Muir K, Henderson B, Kote-Jarai Z, et al. Genetic variants associated with predisposition to prostate cancer and potential clinical implications. J Intern Med. 2012;271:353-65.

47. Demichelis F, Stanford JL. Genetic predisposition to prostate cancer: update and future perspectives. Urol Oncol. 2015;33:75-84.

48. Lurie G, Wilkens LR, Thompson PJ, McDuffie KE, Carney ME, Terada KY, et al. Vitamin D receptor gene polymorphisms and epithelial ovarian cancer risk. Cancer Epidemiol Biomarkers Prev. 2007;16:2566-71.

49. Han J, Colditz GA, Hunter DJ. Polymorphisms in the MTHFR and VDR genes and skin cancer risk. Carcinogenesis. 2007;28:390-7.

50. Guy M, Lowe LC, Bretherton-Watt D, Mansi JL, Peckitt C, Bliss J, et al. Vitamin $D$ receptor gene polymorphisms and breast cancer risk. Clin Cancer Res. 2004;10:5472-81

51. Bai YH, Lu H, Hong D, Lin CC, Yu Z, Chen BC. Vitamin D receptor gene polymorphisms and colorectal cancer risk: a systematic meta-analysis. World J Gastroenterol. 2012;18:1672-9.

52. Yamamoto $\mathrm{H}$, Miyamato $\mathrm{Kl}$, Li BL, Taketani $Y$, Kitano $M$, Inoue $Y$, et al. The caudal-related homeodomain protein $C d x-2$ regulates vitamin $D$ receptor gene expression in the small intestine. J Bone Miner Res. 1999;14:240-7.

53. Arai $\mathrm{H}$, Miyamoto Kl, Yoshida M, Yamamoto $H$, Taketani $Y$, Morita K, et al. The polymorphism in the caudal-related homeodomain protein $\mathrm{Cdx}-2$ binding element in the human vitamin D receptor gene. J Bone Miner Res. 2001;16:1256-64

54. Uitterlinden AG, Fang Y, van Meurs J, Pols H, van Leeuwen J. Genetics and biology of vitamin D receptor polymorphisms. Gene. 2004;338:143-56.
55. Morrison NA, Qi JC, Tokita A, Kelly PJ, Crofts L, Nguyen TV, et al. Prediction of bone density from vitamin D receptor alleles. Nature. 1994;367:284-7.

56. Rowland GW, Schwartz GG, John EM, Ingles SA. Protective effects of low calcium intake and low calcium absorption vitamin $D$ receptor genotype in the California Collaborative Prostate Cancer Study. Cancer Epidemiol Biomarkers Prev. 2013;22:16-24.

57. Schatzl G, Gsur A, Bernhofer G, Haidinger G, Hinteregger S, Vutuc C, et al. Association of vitamin $D$ receptor and 17 hydroxylase gene polymorphisms with benign prostatic hyperplasia and benign prostatic enlargement. Urology. 2001;57:567-72

58. Bousema JT, Bussemakers MJ, van Houwelingen KP, Debruyne FM, Verbeek AL, de La Rosette JJ, et al. Polymorphisms in the vitamin D receptor gene and the androgen receptor gene and the risk of benign prostatic hyperplasia. Eur Urol. 2000:37:234-8.

59. Hamasaki T, Inatomi H, Katoh T, Ikuyama T, Matsumoto T. Significance of vitamin D receptor gene polymorphism for risk and disease severity of prostate cancer and benign prostatic hyperplasia in Japanese. Urol Int. 2002;68:226-31

60. Bashir MN. Epidemiology of prostate cancer. Asian Pac J Cancer Prev. 2015;16:5137-41.

61. Kenfield SA, Chang ST, Chan JM. Diet and lifestyle interventions in active surveillance patients with favorable-risk prostate cancer. Curr Treat Options Oncol. 2007:8:173-96.

62. Wolk A. Diet, lifestyle and risk of prostate cancer. Acta Oncol. 2005:44:277-81.

63. Deng S, Qi J, Stephen M, Qiu L, Yang H. Network-based identification of reliable bio-markers for cancers. J Theor Biol. 2015:383:20-7.

64. Sharma A, Verma HK, Joshi S, Panwar MS, Mandal CC. A link between cold environment and cancer. Tumour Biol. 2015;36:5953-64.

65. Nelson EC, Rodriguez RL, Dawson K, Galvez AF, Evans CP. The interaction of genetic polymorphisms with lifestyle factors: implications for the dietary prevention of prostate cancer. Nutr Cancer. 2008;60:301-12.

66. Wilson KM, Giovannucci EL, Mucci LA. Lifestyle and dietary factors in the prevention of lethal prostate cancer. Asian J Androl. 2012;14:365-74.

67. Discacciati A, Wolk A. Lifestyle and dietary factors in prostate cancer prevention. Recent Results Cancer Res. 2014;202:27-37.

68. Sutcliffe S, Colditz GA. Prostate cancer: is it time to expand the research focus to early-life exposures? Nat Rev Cancer. 2013;13:208-518.

69. Holmberg L, Van Hemelrijck M. The biology and natural history of prostate cancer: a short introduction. Recent Results Cancer Res. 2014;202:1-7.

70. Hu J, Qiu Z, Zhang L, Cui F. Kallikrein 3 and vitamin D receptor polymorphisms: potentials environmental risk factors for prostate cancer. Diagn Pathol. 2014;9:84. doi:10.1186/1746-1596-9-84.

71. Drake I, Wallstrom P, Hindy G, Ericson U, Gullberg B, Bjartell A, et al. TCF7L2 type 2 diabetes risk variant, lifestyle factors, and incidence of prostate cancer. Prostate. 2014;74:1161-70.

72. Risio M, Venesio T, Kolomoets E, Armaroli P, Gallo F, Balsamo A, et al. Genetic polymorphisms of CYP17A1, vitamin D receptor and androgen receptor in Italian heredo-familial and sporadic prostate cancers. Cancer Epidemiol. 2011;35:e18-24.

73. Bai $Y, Y u$ Y, Yu B, Ge J, Ji J, Lu H, et al. Association of vitamin D receptor polymorphisms with the risk of prostate cancer in the Han population of Southern China. BMC Med Genet. 2009;10:125.

74. Chaimuangraj S, Thammachoti R, Ongphiphadhanakul B, Thammavit W. Lack of association of VDR polymorphisms with Thai prostate cancer as compared with benign prostate hyperplasia and controls. Asian Pac J Cancer Prev. 2006;7:136-9. 